\title{
Exogenous and endogenous contributions to nitrogen fluxes in the digestive tract of pigs fed a casein diet. II. Ileal and faecal digestibilities and absorption of amino acids
}

\author{
B Darcy-Vrillon 1, WB Souffrant 2, JP Laplace 1, A Rérat 1, \\ T Corring 1, P Vaugelade 1, G Gebhardt 2, R Köhler 2
}

with the technical assistance of F Bernard, R Calmes, J Jung, MT Morel

1 Station de Physiologie de la Nutrition, INRA - CRJ, 78352 Jouy-en-Josas, France;

${ }^{2}$ Karl-Marx-Universität Leipzig, Sektion Tierproduktion und Veterinärmedizin, Wissenschaftbereich Tierernährungsphysiologie und Futtermittelkunde, 7022 Leipzig, G Kuhn Str 08, Germany

(Received 12 March 1991; accepted 9 July 1991)

\begin{abstract}
Summary - The present work aimed at quantifying nitrogen $(N)$ and amino acid $(A A)$ fluxes in the digestive tract of growing pigs fed a casein diet. In this paper we report on digesta passage at the terminal ileum, on apparent balances at the ileal and faecal levels, and on nutrients appearance in the portal vein. Digesta flow-rate at the terminal ileum was maximum between 6 and $12 \mathrm{~h}$ after the meal. About $10 \%$ of $\mathrm{N}$ and $5 \%$ of total $\mathrm{AA}$ ingested were recovered within $24 \mathrm{~h}$. AA absorption started 30 min after the meal, and was measurable until 13 to $14 \mathrm{~h}$. The total AA absorbed in $24 \mathrm{~h}$ accounted for $128 \%$ of the $A A$ ingested. The AA composition of ileal digesta was very different from that of casein, closely resembling that of endogenous proteins. The AA composition of faeces was very close to that of bacterial proteins. The ileal digestibilities of $A A$, though lower than their faecal values, were very high. This was confirmed by AA absorption balances $>100 \%$. These data suggest that casein was almost totally digested by the terminal ileum, and that endogenous AA were substantially reabsorbed. These findings are supported by data on endogenous $\mathrm{N}$ recycling $\left({ }^{15 \mathrm{~N}}\right)$, reported in a following paper.
\end{abstract}

amino acids / intestine / digestion / absorption / pig

Résumé - Contributions exogènes et endogènes aux flux d'azote dans le tube digestif du porc recevant un régime à base de caséine. Digestibilités iléale et fécale et absorption des acides aminés. Le présent travail a visé à mesurer les flux d'azote $(N)$ et d'acides aminés (AA), exogènes et endogènes, dans le tube digestif du porc en croissance recevant un régime à base de caséine. Les résultats rapportés ici concernent le passage des digesta au niveau de l'iléon terminal, les bilans iléaux et fécaux, et l'apparition des nutriments dans la veine porte. Le débit des digesta iléaux est maximum entre 6 et $12 \mathrm{~h}$ après le repas, et en $24 \mathrm{~h}$ on recueille $10 \%$ environ des quantités de $N$, et $5 \%$ des quantités d'AA ingérées. On peut mesurer l'absorption des nutriments dans la veine porte $30 \mathrm{~min}$ après le repas, et ce pendant $13 \mathrm{~h}$ à $14 \mathrm{~h}$. Les $A A$ totaux absorbés en $24 \mathrm{~h}$ représentent $128 \%$ des AA ingérés. La composition en AA des digesta iléaux diffère beaucoup de celle 
de l'aliment, et ressemble davantage à celle des protéines endogènes, tandis que la composition des fèces reflète celle des protéines bactériennes. Les digestibilités iléales des AA en moyenne inférieures à leurs digestibilités fécales, sont néanmoins très élevées. Ceci est confirmé par des bilans d'absorption des AA supérieurs à 100\%. Ces résultats indiquent une digestion quasi totale de la caséine à l'extrémité de l'iléon, associée à une réabsorption d'AA endogènes. Ces conclusions, basées sur les bilans apparents, doivent être confortées par les mesures de recyclage de l'azote d'origine endogène (N15), rapportées ultérieurement.

acide aminé / intestin / digestion / absorption / porc

\section{INTRODUCTION}

The general purpose of this series of experiments was to determine exogenous and endogenous contribution to $\mathrm{N}$ fluxes in the digestive tract of pigs fed a casein diet. Data on the contribution of the exocrine pancreatic secretion and the bile have been reported in the first paper (Corring et al, 1990).

Several methods have been reported in the literature for measuring protein and amino acid (AA) digestibility, based on the difference between amounts ingested and excreted at a given level of the digestive tract. This was first done at the faecal level (Kuiken and Lyman, 1948) and has been widely used in the pig (Dammers, 1964; Eggum, 1973; Poppe and Meier, 1977). The main bias in this method is due to microbial activity in the large intestine which modifies nitrogenous matter. It comprises both degradation of exogenous and endogenous nitrogenous substrates and synthesis of microbial proteins (Rérat, 1978). Degradation mainly leads to the formation of ammonia which may be absorbed, but afterwards almost fully excreted in the form of urinary urea (Zebrowska, 1973); the extent of microbial protein synthesis depends on the amount of residual fermentable carbohydrates (Mason and Palmer, 1973; Mason et al, 1976; Bergner, 1982). However, the nutritional impact of these modifications seems to be limited as there is almost no $A A$ absorption at that level of the intestine (Zebrowska, 1973). Nevertheless, they may be an important source of error when estimating the apparent digestibility of dietary AA through their faecal digestibility. Consequently, methods based on collection of ileal digesta providing more reliable estimates have been developed over the past 10 years, as emphasized by Zebrowska (1978), Tanksley and Knabe (1982) and Darcy et al (1982).

On the other hand, a method based on the simultaneous measurement of the porto-arterial concentration differences and of the portal blood-flow rate (Rérat et al, 1980) allows the time-course of appearance of nutrients in the efferent blood to be studied and absorption quantified. The aim of the present work was to compare ileal and faecal digestibilities and absorption coefficients for the same casein diet.

\section{MATERIALS AND METHODS}

\section{Animals and experimental design}

Eleven Large White female pigs with a mean body weight of $50.1 \pm 1.8 \mathrm{~kg}$ were used in the experiment. After a period of adaptation, they were kept in restraining cages throughout the experiment. Four of them had an ileo-colic postvalve fistula as described by Darcy et al (1980), involving a post-valve cannula for collection of 
ileal digesta and a colic cannula for their return. Four of them were prepared according to the technique described by Rerat et al (1980). The last 3 were prepared for collection of pancreatic and biliary secretions according to Corring et al (1972) and Juste et al (1979). The animals were progressively refed ( 2 daily means) during a post-operative period of 10 to 14 days. A single semi-synthetic diet including casein (Corring et al, 1990) was given during the whole experiment. The AA composition of the diet is reported in table I.

\section{lleal digesta collection (pigs A to D)}

During the adaptation period, ileal digesta were continuously collected into bags, stored at $4{ }^{\circ} \mathrm{C}$ and then warmed up and returned to the animals once a day after the morning meal.

The experiment was performed after a 24-h fast. The animals received $1 \mathrm{~kg}$ of fresh feed as a single meal. The amount actually ingested averaged $783 \pm 117 \mathrm{~g}$ dry matter. Digesta were collected $6,8,12,16$ and $24 \mathrm{~h}$ after the meal. For each sampling time, the volume and wet amount were recorded and a 100-g aliquot sample taken and stored at $-20^{\circ} \mathrm{C}$.

\section{Absorption studies (pigs $\mathrm{E}$ to $\mathrm{H}$ )}

These animals were surgically fitted with 2 permanent catheters placed in the portal vein and in the carotid artery, and an electro-magnetic flow probe around the portal vein. After recovery and adaptation to the test diet, absorption of a single test-meal was measured, following a 24-h fast, in the same conditions as for pigs $A$ to $D$. The amount actually ingested averaged $840 \pm$ $45 \mathrm{~g}$ dry matter. Blood was sampled from the portal vein and the carotid artery $(2 \times 5 \mathrm{ml})$ each 30 min during the first $6 \mathrm{~h}$ after the meal, each hour from 6 to $14 \mathrm{~h}$, and each $2 \mathrm{~h}$ until the end of the 24-h post-prandial period.

\section{Feces collection (pigs E to K)}

The 7 pigs prepared for absorption measurement (see above) or for collection of pancreatic and biliary secretions (Corring et al, 1990) were also used to measure faecal digestibility. During an 8-day period feed intake was controlled (mean: $1119 \pm 73 \mathrm{~g}$ dry matter) and the daily amount of faeces recorded. An aliquot was taken and stored at $-20^{\circ} \mathrm{C}$.

\section{Analytical methods}

The dry matter (DM) content of diet, digesta and faeces was determined (oven drying $3 \mathrm{~h}$ at $105^{\circ} \mathrm{C}$ ) after freeze-drying. The total nitrogen (N) content was determined according to the Kjeldhal method.

The AA composition of diet, digesta and faeces was determined after acid hydrolysis $(2 h, 2$ atm, $132^{\circ} \mathrm{C}$ ). The sulphur AA content was determined using the same method, after oxidation with performic acid. Free AA were extracted from total blood samples after sulfosalicylic acid precipitation (Beecher, 1978). The AA determined on an AA analyser were Asx (Asp + Asn), Thr, Ser, Glx (Glu + Gln), Pro, Gly, Ala, Val, lle, Leu, Tyr, Phe, Lys, His, Arg, Cys and Met.

\section{Calculations}

The amounts of DM, N and AA drained from the terminal ileum during each time interval between samplings were measured. This allowed the total amount of each of these components collected within $24 \mathrm{~h}$ to be calculated and therefore their apparent ileal digestibilities related to the corresponding quantities ingested. Similar calculations allowed the determinations of faecal apparent digestibilities.

The amounts of $\mathrm{N}$ and $\mathrm{AA}$ absorbed were determined according to the following formulas: $q=(C p-C a) \times D \times d t:$

$$
Q=\sum_{t_{0}}^{t_{1}}
$$

where $q$ is the quantity absorbed during the short time $d t(5 \mathrm{~min})$ during which the factors could be considered as constant; $C p$ is the portal concentration; $\mathrm{Ca}$ the arterial concentration; $D$ the portal blood flow rate and $Q$ the quantity absorbed during the post-prandial period between times $t_{0}$ and $t_{t}$. The 24-h-absorption coefficients were calculated as the ratio between the total amounts absorbed within $24 \mathrm{~h}$ and the corresponding ingested amounts. 


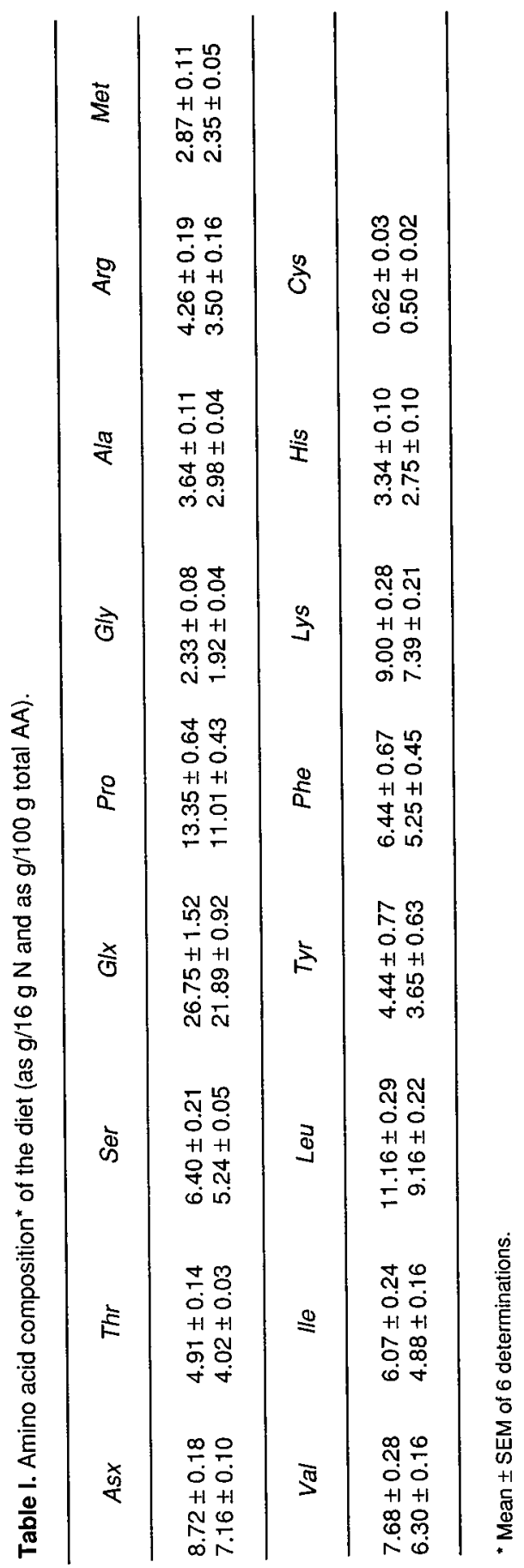




\section{RESULTS}

\section{Time-course of dry matter, nitrogen and amino acid passage in the distal small intestine}

Digesta passage can be described by the total quantities of $\mathrm{DM}$ and $\mathrm{N}$ drained during each of the collection periods. These quantities were expressed as a percentage of the quantities of $\mathrm{DM}$ or $\mathrm{N}$ ingested in order to compare values obtained in pigs $\mathrm{A}, \mathrm{B}, \mathrm{C}$ and $D$. The mean values obtained in the form of hourly flow-rate for each period are reported in figure 1 . The maximum flowrate was recorded between 6 and $12 \mathrm{~h}$ after the meal. DM and $N$ flow-rates were similar until $8 \mathrm{~h}$, whereafter the $\mathrm{N}$ flow-rate was slightly lower. The sum of the 17 AA analysed followed the same kinetics as $D M$ and $N$. However, the hourly flow-rate recorded was always lower than that of $N$. Quantities recovered within $24 \mathrm{~h}$, as a percentage of the corresponding quantities ingested, averaged $10.2 \pm 1.0$ for DM, $9.1 \pm$ 1.1 for $N$ and $5.1 \pm 1.2$ for the sum of $A A$.

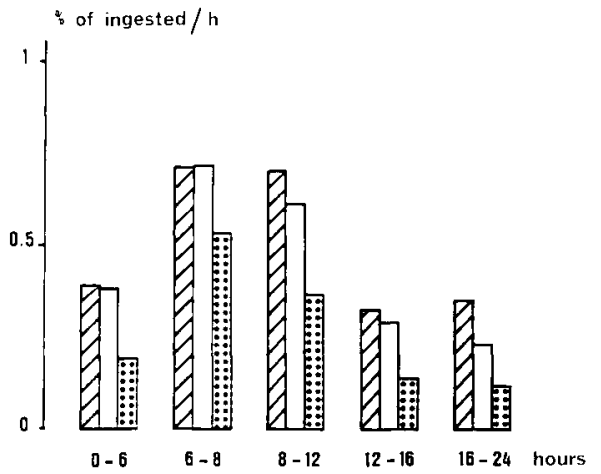

Fig 1. Kinetics of digesta passage in the distal smal I intestine. Hourly flow-rate of dry matter $(\square)$, nitrogen ( $\square$ ) and amino acids ( $\theta$ ), during each of the periods defined by collection time, and expressed in percent of the respective ingested quantities.

\section{Amino acid composition of ileal digesta}

The average AA composition of digesta collected during each period and within $24 \mathrm{~h}$ are reported in figure 2 (AA expressed as percent of the sum of AA collected). For the $24 \mathrm{~h}$ digesta, the most abundant AA were the following, in decreasing order: Glx, Ser, Asx, Leu, Thr, Gly, Pro, Val, Ala, lle Phe, Lys, Tyr, Arg, Cys, His and Met. The AA composition of $24 \mathrm{~h}$ digesta differed greatly from that of the diet. The Ser, Gly, Thr, Ala, Cys and Asx contents were higher in digesta. The Leu, Val, Ile, Tyr, Arg and His contents were similar. Conversely, the proportions of Glx, Pro, Lys, Phe and Met were lower in digesta. Moreover, the digesta contents
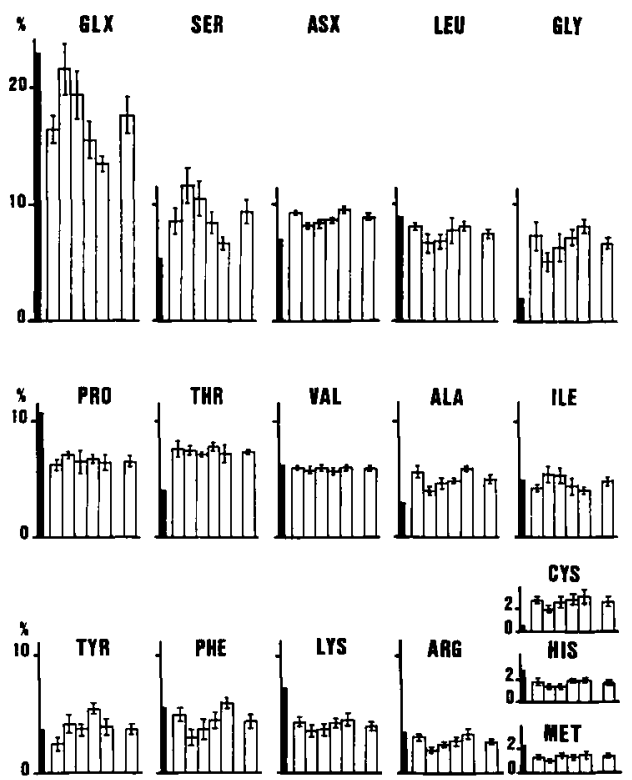

Fig 2. Average composition of digesta during each of the post-prandial intervals. (AA expressed as percent of the sum of 17 AA analysed); the columns, from left to right, correspond to 0 to $6 \mathrm{~h}, 6$ to $8 \mathrm{~h}, 8$ to $12 \mathrm{~h}, 12$ to $16 \mathrm{~h}, 16$ to $24 \mathrm{~h}$ and 0 to $24 \mathrm{~h}$. The hatched columns represent the values determined for the diet. 
varied during the 24-h-period: Glx, Ser, and lle proportions increased and then decreased; the content of some AA did not change with time (Asx, Thr, Val, Cys, Lys, His, Pro and Met); conversely, Leu, Gly, Ala, Phe and Arg proportions decreased and then increased. The AA composition of digesta may also be expressed as $g$ per $16 \mathrm{~g} \mathrm{~N}$ (table II).

\section{Amino acid composition of faeces}

The mean faecal amino acid composition (g AA/ $16 \mathrm{~g} \mathrm{~N}$ ) of pigs $E$ to $K$ is reported in table II. The average contents measured in the ileal digesta $(\mathrm{g} / 16 \mathrm{~g} \mathrm{~N})$ were significantly different from those of the faeces for several AA: Asx, Ala, Phe, Lys, His, Arg and Met. The comparison made on the basis of $\mathrm{g} / 100 \mathrm{~g}$ total amino acids provided more significant differences: a larger proportion of Thr, Pro and Gly in ileal digesta and of Asx, Ala, lle, Lys, His, Arg and Met in faeces.

\section{Apparent digestibility of amino acids}

lleal (pigs $A$ to $D$ ) and faecal (pigs $E$ to $K$ ) digestibilities of each $A A$, of their sum, and of total $\mathrm{N}$ are given in table III. The ileal apparent digestibility of total $\mathrm{N}$ was $91 \%$ while that of the sum of the 17 AA was $95 \%$. The ileal digestibilities of individual AA ranged from $74 \%$ (Cys) to $97 \%$ (Met).

Table II. Amino acid composition of ileal digesta (24-h collection) and of faeces (mean \pm SEM).

\begin{tabular}{|c|c|c|c|c|}
\hline & \multicolumn{2}{|c|}{$g / 100 \mathrm{~g}$ total $A A$} & \multicolumn{2}{|c|}{$g / 16 g N$} \\
\hline & Ileal & Faecal & lleal & Faecal \\
\hline Asx & $8.86^{a} \pm 0.20$ & $10.73^{b} \pm 0.15$ & $6.31^{a} \pm 1.06$ & $9.02^{b} \pm 0.39$ \\
\hline Thr & $7.36^{a} \pm 0.24$ & $5.38^{b} \pm 0.10$ & $5.32 \pm 1.05$ & $4.48 \pm 0.18$ \\
\hline Ser & $9.42 \pm 0.97$ & $7.58 \pm 0.39$ & $7.12 \pm 2.08$ & $6.36 \pm 0.50$ \\
\hline Glx & $17.48 \pm 1.48$ & $16.11 \pm 0.73$ & $13.14 \pm 3.68$ & $13.47 \pm 0.90$ \\
\hline Pro & $6.54^{a} \pm 0.52$ & $5.00^{b} \pm 0.78$ & $4.89 \pm 1.32$ & $4.16 \pm 0.27$ \\
\hline Gly & $6.67^{a} \pm 0.53$ & $5.09^{b} \pm 0.18$ & $4.74 \pm 0.85$ & $4.23 \pm 0.18$ \\
\hline Ala & $5.06^{a} \pm 0.36$ & $5.83^{\mathrm{b}} \pm 0.74$ & $3.52^{a} \pm 0.44$ & $5.43^{b} \pm 0.28$ \\
\hline Val & $5.93 \pm 0.16$ & $6.19 \pm 0.14$ & $4.33 \pm 0.96$ & $5.15 \pm 0.21$ \\
\hline $\mathrm{He}$ & $4.80^{a} \pm 0.42$ & $5.86^{b} \pm 0.12$ & $3.58 \pm 0.96$ & $4.90 \pm 0.26$ \\
\hline Leu & $7.45 \pm 0.26$ & $7.24 \pm 0.18$ & $5.27 \pm 0.82$ & $6.04 \pm 0.29$ \\
\hline Tyr & $3.75 \pm 0.46$ & $3.32 \pm 0.41$ & $2.55 \pm 0.22$ & $2.86 \pm 0.42$ \\
\hline Phe & $4.42 \pm 0.64$ & $4.71 \pm 0.21$ & $2.97^{a} \pm 0.22$ & $3.94^{b} \pm 0.25$ \\
\hline Lys & $4.00^{a} \pm 0.38$ & $5.97^{b} \pm 0.17$ & $2.80^{a} \pm 0.42$ & $5.00^{\mathrm{b}} \pm 0.29$ \\
\hline His & $1.63^{a} \pm 0.19$ & $2.03^{b} \pm 0.08$ & $1.13^{a} \pm 0.14$ & $1.70^{\mathrm{b}} \pm 0.11$ \\
\hline Arg & $2.71^{a} \pm 0.15$ & $3.70^{b} \pm 0.10$ & $1.91^{a} \pm 0.29$ & $3.09^{b} \pm 0.15$ \\
\hline Cys & $2.56 \pm 0.36$ & $2.06 \pm 0.12$ & $1.71^{a} \pm 0.07$ & $1.69^{b} \pm 0.06$ \\
\hline Met & $1.34^{a} \pm 0.17$ & $2.44^{b} \pm 0.11$ & $0.90^{a} \pm 0.02$ & $2.01^{b} \pm 0.06$ \\
\hline Total AA & & & $72.16 \pm 14.12$ & $83.53 \pm 3.74$ \\
\hline
\end{tabular}

Ileal and faecal values bearing different letters in a row differ significantly according to Student's $t$-test $(P<0.05)$. 
Table III. lleal and faecal apparent digestibilities of amino acids (\%, mean \pm SEM).

\begin{tabular}{lcc}
\hline & lleal & Faecal \\
& & \\
\hline Asx & $93.6 \pm 1.5$ & $94.0 \pm 0.6$ \\
Thr & $90.5^{\mathrm{a}} \pm 2.4$ & $94.7^{\mathrm{b}} \pm 0.6$ \\
Ser & $90.3 \pm 3.3$ & $94.4 \pm 0.6$ \\
Glx & $96.0 \pm 1.2$ & $97.0 \pm 0.4$ \\
Pro & $96.8 \pm 1.2$ & $97.7 \pm 0.5$ \\
Gly & $82.1^{\mathrm{a}} \pm 4.2$ & $89.7^{\mathrm{b}} \pm 1.1$ \\
Ala & $91.4 \pm 1.6$ & $91.3 \pm 1.0$ \\
Val & $94.5 \pm 1.4$ & $96.1 \pm 0.4$ \\
lle & $94.2 \pm 1.8$ & $95.2 \pm 0.5$ \\
Leu & $95.6 \pm 1.0$ & $96.9 \pm 0.3$ \\
Tyr & $92.1 \pm 1.4$ & $93.8 \pm 1.5$ \\
Phe & $96.5 \pm 0.9$ & $96.1 \pm 0.5$ \\
Lys & $97.0 \pm 0.6$ & $96.9 \pm 0.4$ \\
His & $96.6 \pm 0.7$ & $97.1 \pm 0.3$ \\
Arg & $95.4 \pm 0.8$ & $95.4 \pm 0.5$ \\
Cys & $74.4^{\mathrm{a}} \pm 4.2$ & $82.7^{\mathrm{b}} \pm 1.1$ \\
Met & $97.1^{\mathrm{a}} \pm 0.4$ & $95.8^{\mathrm{b}} \pm 0.4$ \\
Total AA & $94.7 \pm 1.3$ & $96.0 \pm 0.4$ \\
N & $90.9^{\mathrm{a}} \pm 1.1$ & $94.5^{\mathrm{b}} \pm 0.4$ \\
& & \\
\hline
\end{tabular}

Ileal and faecal values bearing different letters in a row differ significantly according to Student's $t$-test $(P<$ 0.05).

The corresponding faecal values were $95 \%(N)$ and $96 \%$ (sum of $A A$ ). The individual values ranged from $83 \%$ (Cys) to $98 \%$ (Pro). The ileal digestibilities of Thr, Gly, Cys and $N$ were significantly lower than the corresponding faecal digestibilities. The ileal digestibility of Met was higher than its faecal digestibility.

\section{Appearance of amino acids in the blood circulation}

\section{Blood flow-rate and post-prandial variations in nutrient concentrations}

During the experiment, the average blood flow-rate in the portal vein was $2291 \pm 219$ $\mathrm{ml} / \mathrm{min}$, ie $40.4 \pm 5.6 \mathrm{ml} / \mathrm{min}$ per $\mathrm{kg}$ live weight. The postprandial variations of total AA concentrations in the portal vein and carotid artery are reported in figure 3 . There was a very rapid rise of both concentrations within 30 min after the meal, but much more marked in the portal vein than in the carotid artery. These concentrations remained high until $7-8 \mathrm{~h}$ after the meal, and then progressively came back to the preprandial level after 21-22 h. A substantial difference between portal and carotid concentrations was found until $13 \mathrm{~h}$ after the meal.

\section{Absorption coefficients}

The amounts of $\mathrm{AA}$ and $\mathrm{N}$ absorbed within the $24 \mathrm{~h}$ experiment were quantified using

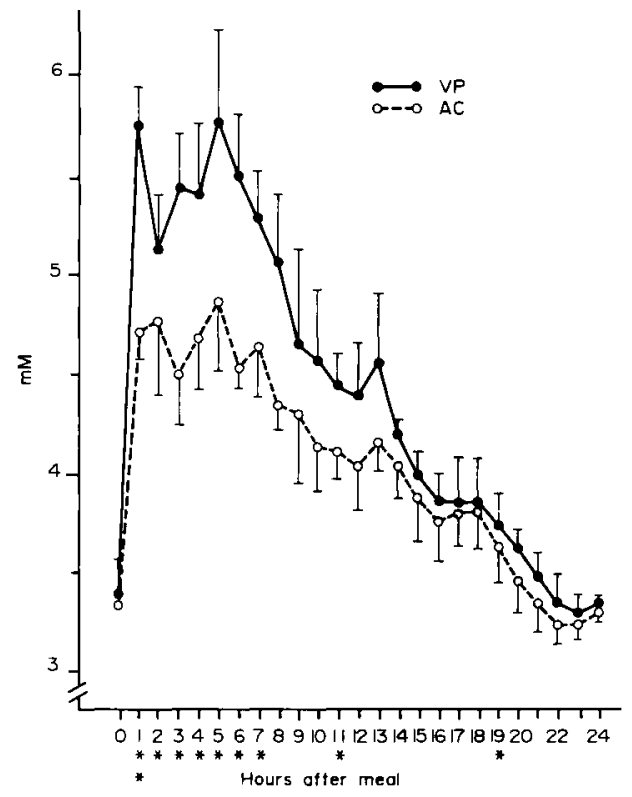

Fig 3. Kinetics of total $A A$ appearance in the blood circulation. Total AA concentrations (mean \pm SEM) in the portal vein (-) , and in the carotid artery (O---O). The asterisks indicate significant differences between portal and carotid concentrations (": $P<0.05$; "*: $P<0.01$ according to Student's $t$-test). 
the concentration differences between venous and arterial blood, and the portal blood flow-rate. Total AA absorbed (sum of $17 \mathrm{AA}$ ) amounted to $1479 \pm 92 \mathrm{mmol}$, $42 \%$ of which was accounted for by essential AA. The corresponding values for the first $8 \mathrm{~h}$ following the test-meal were $819 \pm$ $22 \mathrm{mmol}$, and $45 \%$ essential AA. The corresponding absorption coefficients are given in table IV. The absorption coefficient of total $\mathrm{AA}$ was $72 \%$ at $8 \mathrm{~h}$, and $128 \%$ after $24 \mathrm{~h}$. There was a huge scatter of individual data within the $24 \mathrm{~h}$ experiment, mainly due to the non essential AA.

Table IV. Absorption coefficients of amino acids within $8 \mathrm{~h}$ or $24 \mathrm{~h}$ after the test-meal $(\%$, mean \pm SEM).

\section{$8 h$}

$24 h$

\begin{tabular}{lrr}
\hline & & \\
Asx & $83.6 \pm 16.3$ & $173.2 \pm 30.0$ \\
Thr & $71.1 \pm 9.0$ & $115.1 \pm 9.9$ \\
Ser & $83.2 \pm 12.0$ & $145.8 \pm 22.0$ \\
Glx & $5.1 \pm 2.9$ & $8.8 \pm 5.9$ \\
Pro & $65.5 \pm 7.8$ & $108.5 \pm 8.4$ \\
Gly & $132.2 \pm 27.4$ & $300.3 \pm 43.6$ \\
Ala & $266.0 \pm 17.8$ & $499.7 \pm 12.1$ \\
Val & $81.4 \pm 6.1$ & $131.1 \pm 7.5$ \\
Ile & $74.8 \pm 5.6$ & $120.7 \pm 8.5$ \\
Leu & $64.2 \pm 4.2$ & $98.8 \pm 6.4$ \\
Tyr & $94.2 \pm 5.3$ & $162.7 \pm 10.1$ \\
Phe & $66.4 \pm 1.2$ & $103.4 \pm 6.0$ \\
Lys & $74.1 \pm 5.7$ & $151.4 \pm 11.2$ \\
His & $74.7 \pm 6.2$ & $123.8 \pm 5.9$ \\
Arg & $85.2 \pm 3.3$ & $162.4 \pm 9.3$ \\
Cys & $53.1 \pm 11.5$ & $145.4 \pm 51.4$ \\
Met & $93.5 \pm 2.1$ & $138.1 \pm 8.8$ \\
Total AA & $71.6 \pm 6.1$ & $128.3 \pm 8.8$ \\
N & $80.8 \pm 13.1$ & $139.8 \pm 8.9$ \\
& & \\
\hline
\end{tabular}

\section{DISCUSSION AND CONCLUSION}

The schedule for ileal digesta sampling was chosen according to what was known of the kinetics of digesta passage at the ileo-caeco-colic junction (Darcy et al, 1980). Data from the present experiment (fig 1) were similar to those previously reported for purified diets (Zebrowska et al, 1978a; Darcy et al, 1981; Souffrant et al, 1981). When related to the amounts ingested, the difference between the amounts of $\mathrm{N}$ and the sum of $\mathrm{AA}$ recovered could be explained by the presence of endogenous non protein nitrogen in the ileal digesta (hexosamines, urea), while the latter was non-existent in the diet. This difference, observed on each collection, was found again in the overall balance established at the end of the 24-h experiment.

The marked difference between the AA composition of 24-h digesta and that of the diet can be explained by differences observed in the digestibilities of the various AA. Those with digestibility greater than the average were present in smaller proportions in the digesta than in the diet and conversely. During the post-prandial period, variations in the proportion of each $A A$ in digesta depended on changes in the ratio of exogenous to endogenous proteins and on the relative AA content of these 2 types of protein. Thus, the large increase in the GLX content from 6-12 h after the meal may be due to the large proportion of that $A A$ in the dietary protein used. A reverse phenomenon was observed with other AA such as Gly, Leu, Asx and Ala, ie a decrease in the content of these $A A$ in digesta, during the same period, because of a lower proportion in the diet than in the endogenous proteins. However, the respective AA contents of dietary and endogenous proteins did not always account for 
variations in the $A A$ composition of digesta, as for instance in the case of Ser which increased greatly during the periods $6-8 \mathrm{~h}$ and $8-12 \mathrm{~h}$.

Table II shows that a limited number of differences in AA composition between ileal digesta and faeces reached statistical significance. This can be explained in part by some methodological aspects, as data on digesta composition were derived from $5 \mathrm{AA}$ analyses performed on the various collections within a single 24-h experiment, whereas faecal data were obtained from a single AA analysis on a sample representing an 8-day collection period. Nevertheless, differences in the observed values expressed in $\mathrm{g} / 100 \mathrm{~g} \mathrm{AA}$ can be explained by differences in the proportions of endogenous and bacterial proteins in digesta, and faeces. The larger proportion of AsX, Ala, Ile, Lys, His, Arg and Met in the faeces, as compared to ileal digesta indicated a larger content of bacterial proteins rich in these AA (Mason et al, 1976; Laplace et al, 1985a) in the faeces. To test this hypothesis, we used a $\chi^{2}$ distance calculation, in order to assess the resemblance of the proteins compared (Guilloteau et al, 1983). It showed the closer resemblance between faecal proteins and bacteria $\left(\chi^{2}=69\right)$, than between ileal digesta and the same bacteria $\left(\chi^{2}=229\right)$. Furthermore, the AA composition of ileal digesta or faeces was always very distant from that of the diet $\left(\chi^{2}=354\right.$ and 318 , respectively), a fact which is in agreement with the high digestibility of the dietary protein studied.

Based on individual data, the composition of the faecal proteins remained stable, whatever the level of protein intake in the different trials, whereas that of ileal digesta varied with the amounts ingested on the day of the experiment. These variations can be related to varying proportions of endogenous vs exogenous proteins, according to protein intake. Pigs $A$ and $B$, whose intake was the lowest, had ileal contents with an AA composition resembling most closely that of the endogenous proteins taken as a reference (Darcy et al, 1982): $\chi^{2}=54$ and 106 respectively. Pig C, which had the highest intake, had ileal digesta contents with an AA pattern most distant from the endogenous proteins: $\chi^{2}=307$.

The apparent digestibilities of $\mathrm{N}$ and $\mathrm{AA}$ were generally very high, whatever the site of measurement. This was accompanied by modest differences between the average parameters measured in the ileum vs faeces, a fact generally observed when limited amounts of residual nitrogen reach the large intestine (Darcy, 1982). On average, the faecal digestibility was higher than the ileal. This suggests a preponderance of bacterial degradation over bacterial synthesis, in agreement with most bibliographical data. Nevertheless, the differences between ileal and faecal values depended on the AA considered and could even be reversed when the net result of the bacterial transformations was synthesis. This was observed here for Met, in keeping with most data of the literature (Rérat, 1978). But, once again, there were only few differences reaching statistical significance because of the rather large variability recorded in the ileum. The relative ranking among the ileal apparent digestibilities of the AA studied corresponded rather well to that described in the literature (Darcy et al, 1982), the lowest values being those of Thr, Ser, Gly, Ala and Cys, and the highest those of GIX, Pro, branched chain AA and Met. It should be pointed out that Lys digestibility was high in this casein diet, in agreement with previous data on casein (Ivan and Farrell, 1976; Zebrowska et al, 1978b); this is opposite to what is found for other protein sources such as cereals (Laplace et al, 1985b).

The post-prandial variations in the portal and carotid blood levels of protein nutrients (fig 3) can be compared to those previous- 
ly reported for other dietary proteins. The post prandial increase in the concentration of total $A A$ in both vessels was very rapid, as compared to that observed for cereals (Rérat, 1982), or fish meal proteins (Rérat et al, 1988). This is in agreement with the findings of Galibois et al (1989) for casein. As the porto-arterial concentration difference was maintained until 13-14 h after the meal, the end of digestion of the dietary casein was considered to occur around that time. This length of time is slightly lower than that previously reported for cereal proteins (Rérat, 1981).

On the basis of total AA absorbed within $8 \mathrm{~h}$ after the meal, the absorption coefficients are lower ( $72 \%$ vs $94 \%$ for total $A A)$ than those reported for a casein diet by Galibois et al (1989). Nevertheless, the amount of casein ingested was $25 \%$ lower in the latter study, a fact that may explain a higher level of AA absorption when expressed as a proportion of intake, as previously stated (Rérat et al, 1988a). It must be mentioned that individual absorption coefficients of essential AA do not differ much, when expressed on the basis of total $A A=100$. The only discrepancies are for His which had a lower absorption level in the present study (104 vs 142), and for Val, Met, and Arg which have higher absorption levels (114 to $130 \mathrm{vs}$ around 100). The proportion of essential AA was identical in both studies.

All absorption coefficients based on the 24-h experiment exceeded $100 \%$, so that the quantities of $\mathrm{AA}$ and $\mathrm{N}$ absorbed were larger than the corresponding dietary supplies. This is a common finding in the case of a highly digestible protein, as shown here by ileal digestibility data, and a $24-h$ period of measurement. In such a case, endogenous amino acid absorption accounts for an absorption balance above $100 \%$. Taking into account a mean intake of $155 \mathrm{~g}$ of total AA in the present study, an absorption balance of $128 \%$ means an additional absorption of $42 \mathrm{~g}$ of total AA. This figure is very much in line with the 2 $\mathrm{g} / \mathrm{h}$ of endogenous AA absorbed in pigs fed a protein-free diet (Rérat et $a l, 1988 \mathrm{~b}$ ).

Whatever the time considered, $\mathrm{N}$ absorption was higher than that of the sum of $17 \mathrm{AA}$. This difference was due to the additional absorption of $\mathrm{N}$ in the form of non dietary AA (citrulline, ornithine), and non protein $\mathrm{N}$ (urea, amines).

The dispersion of the absorption coefficient values calculated over $24 \mathrm{~h}$, mainly due to the non-essential $A A$, is related to the metabolism including transaminations in the intestinal mucosa. The appearance of large excesses of Ala and Gly, and a marked deficit of Glx correspond to the metabolism of these AA (Neame and Wiseman, 1957, 1958; Pion et al, 1963, 1964). According to a much narrower range of values for essential $A A$, the mixture of essential AA absorbed was only slightly modified, as previously shown (Rérat, 1982). Nevertheless, the comparison of the AA profiles at 8 and $24 \mathrm{~h}$ (on the basis of the absorption coefficient of total $A A=100$ ) suggests that Lys and Cys were absorbed rather slowly, whereas Met, Val, and branched-chain $A A$ tended to be quickly absorbed. This behaviour of Lys is similar to that previously reported for cereal or fish proteins (Rérat, 1982).

The comparison of ileal digestibility and absorption coefficient values is illustrated in figure 4. Both parameters supplied high values on an average: a little lower than $100 \%$ for digestibility and higher than $100 \%$ for absorption, accounting for almost total digestion of casein in our experimental conditions. Differences between AA were only small as regards digestibility; they were larger for the absorption coefficients. With this highly digested diet, and a 24-h period of measurement, the absorp- 

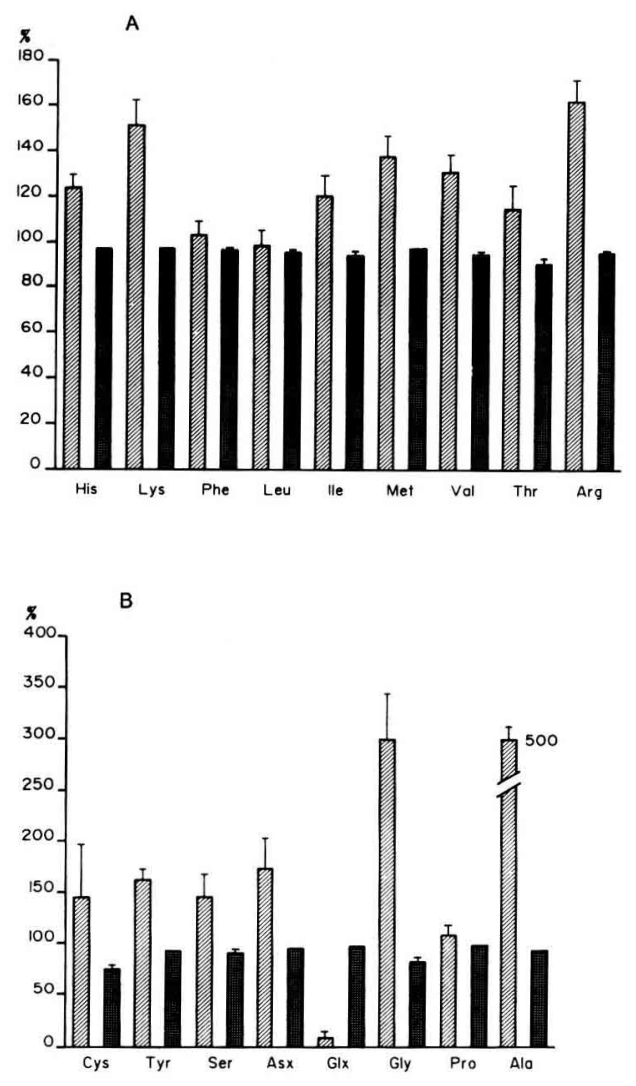

Fig 4. Comparison of ileal apparent digestibilities and absorption coefficients. $A$ : essential $A A$; $B$ : non essential AA; : ileal digestibility; absorption coefficient.

tion values were higher than the apparent digestibilities, the opposite being generally observed on a shorter period of measurement (Darcy and Rérat, 1983). It should be pointed out that the endogenous fraction affects both parameters, but differently, as endogenous $N$ in digesta reduces the apparent digestibility, whereas the endogenous $\mathrm{N}$ reabsorbed increases the absorption coefficient.
The high digestibility values reported in this paper suggest that digestion of casein is almost total in the present experimental conditions. This aspect will be specifically examined on the basis of isotopic labeling data $\left({ }^{15 N}\right)$ reported in a following paper.

\section{REFERENCES}

Beecher GR (1978) Design and assembly of an inexpensive, automated microbore aminoacid analyser: separation and quantitation of aminoacids in physiological fluids. In: Nutritional Improvement of Food and Feed Proteins (Friedman $M$, ed) Plenum Press, NY, 827-840

Bergner $H$ (1982) The importance of crude fibre in the nutrition of monogastric animals. Monatsh Veterinärmed 37, 58-66

Corring $T$, Souffrant WB, Darcy-Vrillon B, Gebhardt G, Laplace JP, Rérat A (1990) Exogenous and endogenous contribution to nitrogen fluxes in the digestive tract of pigs fed a casein diet. 1. Contributions of nitrogen from the exocrine pancreatic secretion and the bile. Reprod Nutr Dev 30, 717-722

Corring T, Aumaitre A, Rérat A (1972) Fistulation permanente du pancreas exocrine chez le porc. Application : réponse de la sécrétion pancréatique au repas. Ann Biol Anim Biochim Biophys 12, 109-124

Dammers J (1964) Digestibility in the pig. Factors influencing the digestion of the components of the feed and the digestibility of the amino-acids. Thesis, Université van Leuven, p 152

Darcy B (1982) Transit et digestion dans l'intestin grêle chez le porc. In : Physiologie Digestive chez le Porc. Colloq INRA, No 12, INRA Publ, Versailles

Darcy B, Rérat A (1983) Protein digestion and absorption of the hydrolysis products in the small intestine of the pig. In: 4 th int Symp Protein Metab Nutr, Clermont-Ferrand, 5-9 Sept 1983. Colloq INRA No 16, INRA Publ, Versailles

Darcy B, Laplace JP, Villiers PA (1980) Digestion dans l'intestin grêle chez le porc. 2 . Cinétique comparée de passage des digesta sel- 
on le mode de fistulation, iléo-caecale ou iléocolique post-valvulaire, dans diverses conditions d'alimentation. Ann Zootech 29, 147-177

Darcy B, Laplace JP, Villiers PA (1981) Digestion dans l'intestin grêle chez le porc. 4. Cinétique de passage des digesta au niveau de la jonction iléo-caeco-colique et bilans de la digestion selon la nature de l'amidon et de la source de protéines alimentaires. Ann Zootech 30, 31-62

Darcy B, Laplace JP, Duée PH (1982) Digestion des protéines dans l'intestin grêle chez le porc. 1. Digestibilité des acides aminés selon la source de protéines d'un régime à base d'amidon de maïs purifié. Ann Zootech 31, 279-300

Eggum BO (1973) A study of certain factors influencing protein utilization in rats and pigs. Beret Forsogslab 406, $173 p$

Galibois I, Simoes Nunes C, Rérat A, Savoie L (1989) Net appearance of amino acids in portal blood during the digestion of casein or rapeseed proteins in the pig. Can J Physiol Pharmacol 67, 1409-1417

Guilloteau $P$, Sauvant D, Patureau-Mirand $P$ (1983) Methods of comparing amino acid composition of proteins: application to undigested proteins in the preruminant calf. Ann Nutr Metab 27, 457-469

Ivan M, Farrell DJ (1976) Nutritional evaluation of wheat. 5. Disappearance of components in digesta of pigs prepared with two reentrant cannulae. Anim Prod 23, 111-119

Juste $C$, Corring T, Breant $P$ (1979) Excrétion biliaire chez le porc : niveau et réponse au repas. Ann Biol Anim Biochim Biophys 19, 79-90

Kuiken KA, Lyman CM (1948) Availability of amino acids in some foods. J Nutr 36, 359368

Laplace JP, Darcy-Vrillon B, Duval-Iflah Y, Raibaud $P$ (1985a) Proteins in the digesta of the pig: amino acid composition of endogenous bacterial and fecal fractions. Reprod Nutr Dev 25, 1083-1099

Laplace JP, Darcy-Vrillon B, Picard M (1985b) Évaluation de la disponibilité des acides aminés : choix raisonné d'une méthode. Journées Rech Porcine France 17, 353-370
Mason VC, Palmer R (1973) The influence of bacterial activity in the alimentary canal of rats on faecal nitrogen excretion. Acta Agric Scand 23 (3), 141-150

Mason VC, Just A, Bech-Andersen S (1976) Bacterial activity in the hind-gut of pigs. 2. Its influence on the apparent digestibility of nitrogen and amino acids. $Z$ Tierphysiol Tierernähr Futtermittelk 36, 310-324

Neame KD, Wiseman G (1957) The transamination of glutamic and aspartic acids during absorption by the small intestine of the dog in vivo. J Physiol (Lond) 135, 442-450

Neame KD, Wiseman G (1958) The alanine and oxoacid concentrations in mesenteric blood during the absorption of L-glutamic acid by the small intestine of the dog, cat, and rabbit in vivo. J Physiol (Lond) 140, 148-155

Pion R, Fauconneau G, Rérat A (1963) Étude cinétique de la composition en acides aminés du sang porte chez le porc. Ann Biol Anim Biochim Biophys 3, 31-37

Pion R, Fauconneau G, Rérat A (1964) Variation de la composition en acides aminés du sang porte au cours de la digestion chez le porc. Ann Biol Anim Biochim Biophys 4, 383402

Poppe S, Meier H (1977) Assessment of true digestibility of amino acids and its value in swine. Proc 2nd Int Symp on Protein Metabolism and Nutrition, Flevohof, The Netherlands

Rérat A (1978) Digestion and absorption of carbohydrates and nitrogenous matters in the hindgut of the omnivorous non-ruminant animal. J Anim Sci 46, 1808-1837

Rérat A (1981) Chronologie et bilans de l'absorption des sucres réducteurs et de l'azote $\alpha$ aminé chez le porc selon la nature des aliments. Bull Acad Natl Med 165, 11311137

Rérat A (1982) Absorption des sucres et des acides aminés chez le porc. In : Physiologie Digestive chez le Porc. Les Colloques de I'INRA, No 12, INRA Publ, Versailles

Rérat A, Vaugelade P, Villiers PA (1980) A new method for measuring the absorption of nutrients in the pig: critical examination. In: Current Concepts of Digestion and Absorption in Pigs (Low AG, Partridge IG, eds) NIRD Press, Reading, UK 
Rérat A, Jung J, Kande J (1988a) Absorption kinetics of dietary hydrolysis products in conscious pigs given diets with different amounts of fish protein. 2. Individual amino acids. $B r J$ Nutr 60, 105-120

Rérat A, Vaissade P, Vaugelade P (1988b) Quantitative measurement of endogenous amino acid absorption in unanaesthetized pigs. Arch Anim Nutr (Berl) 38, 463-479

Souffrant WB, Köhler R, Gebhardt G (1981) Untersuchungen zur Bestimmung der endogenen N-Sekretion in dünndarm bei Schweinen. Arch Tierernähr 31, 35-43

Tanksley TD, Knabe DA (1982) Researchers outline amino acid digestibilities of some high-protein feedstuffs and use in swine diet formulations. Feedstuffs 54, 16-31
Zebrowska T (1973) Digestion and absorption of nitrogenous compounds in the large intestine of pigs. Rocz Nauk Roln 95 B, 85-90

Zebrowska T (1978) Determination of available amino acids in feedstuffs for monogastrics. Feedstuffs 50, 15-17, 43-44

Zebrowska T, Gebhardt G, Köhler R (1978a) Untersuchungen zur Stickstoff- und Aminosäurenabsorption beim Schwein. 1. Die Passage des Chymus im Dünndarm. Arch Tierernähr 28, 3-10

Zebrowska T, Buraczewska L, Pastuszewka B (1978b) Effect of diet and method of collection on amino acid composition of ileal digesta and digestibility of $N$ and amino acids in pigs. Rocz Nauk Roln Ser B Zootech 99, 75-83 